\title{
Assessment of Secondary School Administration: The Communities Perspectives
}

\author{
Enamiroro Patrick Oghuvbu* and James Okoro** \\ *Department of Educational Administration and Policy Studies, **Institute of Education, \\ Delta State University, Abraka, Nigeria \\ *E-mail: Enamiroro2001@Yahoo.Com
}

KEYWORDS Communities; activities; assessment; discipline; development

\begin{abstract}
The study examined the contributions of community leaders in the assessment of secondary school administration in Nigeria. It also identified ways of enhancing the administration of secondary schools as perceived by community leaders. A forty-seven items questionnaire was administered to 4200 respondents used in this study. Three research questions were raised and answered using percentages. Five hypotheses were formulated and tested using chi-square at 0.05 level of significance. The study revealed that, secondary school principals and teachers are dedicated to duty. Sex and location of communities do not affect the perception of community leaders in principals and teachers dedication to duty and contribution toward community development, student disciplines and involvement in community activities in secondary schools in Nigeria.
\end{abstract}

\section{INTRODUCTION}

Education in Nigeria is an instrument "par excellence" for effecting national development. It has witnessed active participation by nongovernment agencies, communities and individuals as well as government intervention (NPE, 1998). A school is in a sense a small community consisting of staff and pupils which has its own pattern of rules and regulations and at the same time is an integral part of a much wider community with its pattern of thinking, individuals and social organisations that influence thought and action. In other words, the school does not exist alone. It is a social institutions, an agency by which desirable social needs may be met and therefore a means to an end and not an end in itself. A school derives its existence and life blood from the community is situated which often supports it with her materials and human resources (Akubue, 1997).

In the Nigerian school system, there are changes in the control of schools which have produced corresponding changes in the type of community involved and interest in school activities. To convey some historical insight, one may remember that with the introduction western education by missionaries in 1884 each mission became a significant member of the community. The participation of the colonial government in the administration of schools programmes beginning from 1886, further increased the size of the community school in 1970, the East Central State Government took over school control and engaged communities to build schools, a situation which brought schools face to face with the political, social, economic and religious life of the community.

In the same vein, the relationship between the community and the school in the funding of education cannot be over emphasized. The community has immense input in the funding of educational projects such as endowment funding, sponsoring of projects and Parents Teachers Association involvement (Okoro and Okoro, 2005). All these indicate that the communities and the school exist side by side and always been in existence, as a pre-existing condition for effective schools management. Chibulka (1978) in Akubue (1997) described a community as a people obliged to one another not because of place of birth, race, sex, religion but people bound to one another and governed by shared taste, value, specific words for common interest. Throughout history, the relationship of the school to the community it serves has been a matter of major concern. Ozigi (1977) opened that it is important that the school and the community should have mutual relationship to foster cordial existence.

The community where the school is situated form a focus point of assessing the activities of the school and make necessary contributions towards its growth. Activities of the principals, teachers and students are assessed by the 
community. The community assessment of school is mostly effective in secondary school than tertiary education. A good school community relationship could results into: accommodation of students of different background and ability within the school programmes, building the school foundation on the needs of the community, leading to the growth in all its ramifications for the good of the citizens. The curriculum and school is usually sensitive to the nature and needs of the community (Ogbebor, 1992: 143).

Communities in Nigeria, assist in the administration of schools through the provision of instructional facilities, protection of school properties, seeking government assistance in the provision of facilities (Oghuvbu and Iyeke, 2004). As a result, all the intra-organisations, students, non-teaching staff, intimately connected with the school should be effectively mobilized.

\section{Purpose and Significance of the Study}

Some of the objective of secondary education in Nigeria as stated in the National Policy of Education (NPE, 1998: 17) are: Development and promotion of Nigerian languages, art and culture in the context of world cultural heritage. Inspire students with a desire for self improvement and achievement of excellence. Raise a generation of people who can think for themselves, respect the views and feelings of others, respect the dignity of labour, appreciate those values specified under our broad national goals and live as good citizens. Amongst such national goals is the full integration of the individual into the community; and better human relationship, national unity as well as towards social, cultural, economic, political. Scientific and technological development.

These well stated objectives if achieved could lead to scientific and technological development. Forty years after independent, Nigeria is in the group of under-developed countries, characterized by increase in dropout rate from school at all levels of the education system, rural urban migration, teenage girl involving themselves in international prostitution, lack of respect for elders, teachers and school authority by youths.

In assessing principals administrative effectiveness Oghuvbu (2000), focused on leadership, supervision of institution and relationship with community, based on male and female teacher perception. Also in assessing teachers effectiveness in Nigeria secondary school Akpotu and
Oghuvbu (2004) focused on teachers, classroom attendance, competency in content and pedagogy, relationship with students and disciplinary qualities based on secondary school students perception.

A large percentage of the population that complains about poor quality of secondary education is residents in various communities. These residents are the producers of school raw materials (children) and the consumers of the products of the schools. Since community residents are the immediate users and those who bear the positive and negative consequences of ineffective and inefficient secondary school administration, this study is deigned to identify the significant role which community leaders can play in assisting school administration in addressing this problem.

Specially, the purpose of this paper is to empirically test community's assessment of secondary school administration to ascertain the perception of the general public on the quality of secondary education in terms of production of good quality, disciplined and skilled manpower for the labour market and students for tertiary institutions.

\section{Research Questions}

The following research questions were raised and answered.

1. What are community leader's perceptions of secondary school administration in Nigeria?

2. In what ways could secondary schools administration be enhanced in Nigeria?

3. What is the general assessment of secondary school administration by community leaders in Nigeria?

\section{Hypotheses}

The following hypotheses were formulated and tested.

1. Gender has no significant influence on community leaders' perception on teachers' dedication to duty and involvement in community development.

2. Sex has no significant influence on community leaders' perception on students discipline and involvement in community development.

3. Principals' administrative effectiveness does not significantly influence schools contribution towards community development as perceived by community leaders. 
4. Gender does not significantly influence community leaders' perception on the identified ways of enhancing the effective administration of secondary schools in Nigeria.

5. School location has no significant influence on community leaders' perception on the general assessment of secondary school administration in Nigeria.

\section{METHODOLOGY}

A sample of 4200 community leaders was drawn using the stratified and cluster sampling techniques twelve states, two from each of the six geo-political zones that made up the thirty-six states of the Federal Republic of Nigeria. One hundred and twenty communities were used in this study. The sample was made up of 756 male urban leaders, 504 female urban leaders, 756 male semi-urban leaders, 504 female semi-urban leaders, 1008 male rural leaders and 672 female rural leaders i.e. (4200 respondents). Only within the communities and above 45 years in age were used for this study.

The instrument for data collection was a fortythree (43) items questionnaire patterned after fourLikert point scale. Oral interview was also conducted among the rural respondents using the questionnaire, designed to elicit responses on principals and teachers administrative competence in terms of discipline, dedication to duty, involvement/contributions towards community development and student qualities, (Bunnell, 1995).
The interment was first administered on 20 set of community leaders within an interval of two weeks. The result of the test-re-0test reliability coefficient was 0.86 . This was also a measure of internal consistency of the instrument. Hence the coefficient of 0.86 is an indication of strong interitems relationship and validity of the instrument. Descriptive statistics grand percentage was used to identify male and female community leaders' perception on principals, teachers' effectiveness and students' quality in Nigeria secondary schools. The inferential statistics, chi-square was used in the analysis of the five null hypotheses at 0.05 level of significance.

\section{Collection of Data}

Each subject was scored on the basis of his/ her response to the statement. Scoring was done in order of strongly agree (SA) 4, agree (A) 3, Disagree (s) 2 and strongly disagree (DS) 1 . This was used to answer the research questions strongly disagree used as disagree in the analysis of the five null hypotheses.

\section{RESULTS}

Research Questions: What are community's leaders' perceptions of secondary school administration in Nigeria?

The result in table 1 , showed that urban, semiurban rural, male and female community leaders are not satisfied with contribution towards

Table 1: Summary of community leader's perception of principals, teachers and students dedication to duty and contribution towards community development.

\begin{tabular}{|c|c|c|c|c|c|}
\hline $\begin{array}{l}\text { S. } \\
\text { No. }\end{array}$ & Items & $\begin{array}{l}\text { Principals } \\
\text { Score } / \%\end{array}$ & $\begin{array}{l}\text { Teachers } \\
\text { Score/\% }\end{array}$ & $\begin{array}{l}\text { Students } \\
\text { Score } \%\end{array}$ & $\begin{array}{l}\text { Grand total } \\
\text { /Overall \% }\end{array}$ \\
\hline \multirow[t]{2}{*}{1} & Discipline of students & 73483 & 9487 & & 82970 \\
\hline & & 72.9 & 56.47 & - & 64.68 \\
\hline \multirow[t]{2}{*}{2} & Contribution towards & 11215 & 34836 & 10870 & 56921 \\
\hline & community development & 66.76 & 51.83 & 64.70 & 56.47 \\
\hline \multirow[t]{2}{*}{3} & Self control / discipline & 59593 & 34378 & 53256 & 147227 \\
\hline & & 59.12 & 68.21 & 63.40 & 67.41 \\
\hline \multirow[t]{2}{*}{4} & Dedication to duty / studies & 11259 & 12072 & 19942 & 43273 \\
\hline & Ability to read and write the language & $\begin{array}{c}67.02 \\
7056\end{array}$ & $\begin{array}{c}71.86 \\
6117\end{array}$ & $\begin{array}{r}59.35 \\
21242\end{array}$ & $\begin{aligned} 64.39 & \\
34416 & \end{aligned}$ \\
\hline 5 & $\begin{array}{l}\text { and educated in the culture of the } \\
\text { community }\end{array}$ & 42 & 36.41 & 63.22 & 51.21 \\
\hline \multirow[t]{2}{*}{6} & Produce local facilities using local & 6386 & 3528 & 9931 & 19845 \\
\hline & community materials & 38.01 & 21 & 59.12 & 39.38 \\
\hline 7 & Discipline of teachers & 23597 & - & - & 23597 \\
\hline \multirow{2}{*}{\multicolumn{2}{|c|}{ Total }} & $\begin{array}{c}70.28 \\
192589\end{array}$ & 100418 & 115241 & $\begin{array}{l}70.28 \\
408248\end{array}$ \\
\hline & & 63.69 & 66.41 & 62.36 & 62.30 \\
\hline
\end{tabular}

Source: Computed from fieldwork 
community development, ability to read and write the language of the community and production of local facilities. They are satisfied with selfcontrol, discipline of students and teachers by principals of secondary schools in Nigeria.

Question 2: In what ways could secondary school administration be enhanced in Nigeria?

The result in table 2 revealed that secondary school administration could be enhanced by setting up education development and monitoring committee in all communities and establishment of effective Parent Teachers Association in every school under the control of the community leaders.

Question 3: What is the general assessment of secondary school administration by community leader's in Nigeria?

The result in table 3 revealed that only female semi-urban residents are satisfied with secondary school administration in Nigeria. The general assessment is unsatisfactory.

Hypothesis 1: Gender has no significant influence on community leaders' perception on teachers' dedication to duty and involvement in community development.

Df $=9$ chi-square cal $=14.602, \chi^{2}$ table value $=16.92$. Result is not significant at 0.05.

Since calculated chi - square value is less than chi-square table value i.e. $14.602<16.92$ result is not significant and null hypothesis accepted. There is no difference among the perception of male, female community leaders, retired male, female teachers, men leader, female leader, church male and female leaders and other community leaders on the quality of teachers in terms of dedication and involvement in community activities.

Hypothesis 2: Sex has no significant influence on community leaders' perception on students discipline and involvement in community development.

Df $=9$ chi-square cal $=8.6049, \chi^{2}$ table value $=16.92$. Result is not significant at 0.05

Since calculated chi - square value of 8.6049 is less than chi-square table value of 16.92 results is not significant and null hypothesis accepted. There is no difference between the perception of male, female community leaders on the quality of students in terms of discipline and involvement in community, language, facilities and cultural development in Nigeria.

Hypothesis 3: Principals administrative effectiveness does not significantly influence schools contribution towards community development as perceived by community leaders.

Table 2: Identified ways of enhancing the administration of secondary schools by community leaders in Nigeria.

\begin{tabular}{|c|c|c|c|c|c|}
\hline $\begin{array}{l}\text { S. } \\
\text { No. }\end{array}$ & Items & $\begin{array}{l}\text { Maximum } \\
\text { Score } 1 \%\end{array}$ & Mean & $\begin{array}{l}\text { Agree } \\
\text { No. } \%\end{array}$ & $\begin{array}{c}\text { Disagree } \\
\text { No. } \%\end{array}$ \\
\hline 1 & $\begin{array}{l}\text { Set up education development and } \\
\text { monitoring committee in all communities }\end{array}$ & $\begin{array}{r}13023 \\
77.52\end{array}$ & 3.1 & $\begin{array}{l}3376 \\
80.38\end{array}$ & $\begin{array}{r}824 \\
19.62\end{array}$ \\
\hline 2 & $\begin{array}{l}\text { Establishment of an effective parent teacher } \\
\text { association in every school under the control } \\
\text { of the community leaders }\end{array}$ & $\begin{array}{r}11584 \\
68.95\end{array}$ & 2.76 & $\begin{array}{l}2774 \\
66.05\end{array}$ & $\begin{array}{r}1426 \\
33.95\end{array}$ \\
\hline 3 & $\begin{array}{l}\text { Establishment of school board of governor's } \\
\text { under the control of community leaders }\end{array}$ & $\begin{array}{r}10347 \\
61.58\end{array}$ & 2.46 & $\begin{array}{r}2201 \\
52.41\end{array}$ & $\begin{array}{r}1999 \\
47.59\end{array}$ \\
\hline 4 & $\begin{array}{l}\text { Indigenes of the community should head and } \\
\text { teacher community schools } \\
\text { Total }\end{array}$ & $\begin{array}{c}10233 \\
60.91 \\
45187 \\
67.24\end{array}$ & $\begin{array}{l}2.44 \\
2.69\end{array}$ & $\begin{array}{r}1848 \\
44 \\
10199 \\
60.71\end{array}$ & $\begin{array}{r}2352 \\
56 \\
6601 \\
39.29\end{array}$ \\
\hline
\end{tabular}

Source: Computed form fieldwork

Table 3: General assessment of secondary school administration by community leaders in Nigeria.

\begin{tabular}{llccl}
\hline S. No. & Items & Score / \% & Mean & Remark \\
\hline 1 & Male Urban & $1733(57.29)$ & 2.29 & Unsatisfactory \\
2 & Female Urban & $1036(51.4)$ & 2.06 & Unsatisfactory \\
3 & Male Semi - Urban & $1727(57.10)$ & 2.28 & Unsatisfactory \\
4 & Female Semi - urban & $1315(65.23)$ & 2.61 & Satisfactory \\
5 & Male Rural & $2294(56.90)$ & 2.28 & Unsatisfactory \\
\hline & Total & $9712(57.81)$ & 2.31 & Unsatisfactory \\
\hline
\end{tabular}

Source: Computed from fieldwork 
Df $=9$ chi-square cal $=18.26, \chi^{2}$ table value $=16.92$ Result is significant at 0.05

Since chi-square calculated value of 81.26 is greater than chi-square table value of 16.92 , result is significant reject null hypothesis. Principals' administrative effectiveness significantly influences secondary schools contribution towards community development in Nigerian.

Table 4: Chi-square contingency table showing the views of community leaders, retired teachers, church leaders, men leaders, women leaders and other elders on the quality of teachers in terms of dedication to duty and involvement in community activities.

\begin{tabular}{|c|c|c|c|c|}
\hline \multirow{2}{*}{$\begin{array}{l}S . \\
\text { No. }\end{array}$} & \multirow[t]{2}{*}{ Sex / Type of Leaders } & \multicolumn{2}{|c|}{ Two Likert Scale } & \multirow[t]{2}{*}{ Total } \\
\hline & & Agree & Disagree & \\
\hline 1 & Male Executive Leader & $345(344.1)$ & $215(215.9)$ & 560 \\
\hline 2 & Female Executive Leader & $92(86)$ & $48 \quad(54)$ & 140 \\
\hline 3 & Male Retired Teacher & $347 \quad(344.1)$ & $213(215.9)$ & 560 \\
\hline 4 & Female Retired Teacher & $88 \quad(86)$ & $52 \quad(54.1)$ & 140 \\
\hline 5 & Male Church Leader & 185 (215) & $163(134.9)$ & 350 \\
\hline 6 & Female Church Leader & $217(215)$ & $133(134.9)$ & 350 \\
\hline 7 & Men Leader & $434 \quad(430.2)$ & $266 \quad(269.8)$ & 700 \\
\hline 8 & Women Leader & $443(430.2)$ & $257(269.8)$ & 700 \\
\hline 9 & Other Male Elder & $208(215)$ & $142(134.9)$ & 350 \\
\hline \multirow[t]{2}{*}{10} & Other Female Elder & $222(215)$ & $128(134.9)$ & 350 \\
\hline & Total & 2581 & 1619 & 4200 \\
\hline
\end{tabular}

Source: Computed from fieldwork

Table 5: Chi-square contingency table showing the male and female community leaders perception on students discipline and involvement in community development.

\begin{tabular}{|c|c|c|c|c|}
\hline \multirow{2}{*}{$\begin{array}{l}S . \\
\text { No. }\end{array}$} & \multirow[t]{2}{*}{ Sex / Type of Leaders } & \multicolumn{2}{|c|}{ Two Likert Scale } & \multirow[t]{2}{*}{ Total } \\
\hline & & Agree & Disagree & \\
\hline 1 & Male Executive Leader & $273(282.1)$ & $287 \quad(277.9)$ & 560 \\
\hline 2 & Female Executive Leader & $(70.5)$ & $72 \quad(69.5)$ & 140 \\
\hline 3 & Male Retired Teacher & $293(282.1)$ & $276 \quad(277.9)$ & 560 \\
\hline 4 & Female Retired Teacher & $80 \quad(70.5)$ & $60 \quad(69.5)$ & 140 \\
\hline 5 & Male Church Leader & $174(179.3)$ & $176(173.7)$ & 350 \\
\hline 6 & Female Church Leader & $188 \quad(176.3)$ & $162(173.7)$ & 350 \\
\hline 7 & Men Leader & $342(352.2)$ & $358 \quad(347.3)$ & 700 \\
\hline 8 & Women Leader & $336 \quad(352.7)$ & $364(347.3)$ & 700 \\
\hline 9 & Other Male Elder & $180(176.3)$ & $170 \quad(173.7)$ & 350 \\
\hline \multirow[t]{2}{*}{10} & Other Female Elder & $182(176.3)$ & $168(173.7)$ & 350 \\
\hline & Total & 2116 & 2084 & 4200 \\
\hline
\end{tabular}

Source: Computed from fieldwork

Table 6: Chi-square contingency table showing the perception of male and female community under principals' administrative effectiveness in terms of staff, student and self discipline and contribution towards community development.

\begin{tabular}{|c|c|c|c|c|}
\hline \multirow{2}{*}{$\begin{array}{l}S . \\
\text { No. }\end{array}$} & \multirow[t]{2}{*}{ Sex / Type of Leaders } & \multicolumn{2}{|c|}{ Two Likert Scale } & \multirow[t]{2}{*}{ Total } \\
\hline & & Agree & Disagree & \\
\hline 1 & Male Executive Leader & $206(205.3)$ & $354(354.7)$ & 560 \\
\hline 2 & Female Executive Leader & $54 \quad(51.3)$ & $86 \quad(88.7)$ & 140 \\
\hline 3 & Male Retired Teacher & $242(205.3)$ & $318 \quad(354.7)$ & 560 \\
\hline 4 & Female Retired Teacher & $64 \quad(51.3)$ & $76 \quad(88.7)$ & 140 \\
\hline 5 & Male Church Leader & $129(128.3)$ & $221 \quad(221.7)$ & 350 \\
\hline 6 & Female Church Leader & $124(128.3)$ & $226 \quad(221.7)$ & 350 \\
\hline 7 & Men Leader & $160(256.7)$ & $540 \quad(443.3)$ & 700 \\
\hline 8 & Women Leader & $283(256.7)$ & $417 \quad(443.3)$ & 700 \\
\hline 9 & Other Male Elder & $145(128.3)$ & $205 \quad(221.7)$ & 350 \\
\hline \multirow[t]{2}{*}{10} & Other Female Elder & $133(128.3)$ & $217(221.7)$ & 350 \\
\hline & Total & 1540 & 2660 & 4200 \\
\hline
\end{tabular}

Source: Computed from fieldwork 
Hypothesis 4: Gender does not significantly influence community leaders' perception on the identified ways of enhancing the effective administration of secondary schools in Nigeria.

$\mathrm{Df}=9$ chi-square cal $=7.890, \chi^{2}$ table value $=16.92$ Result is significant at 0.05

Since chi-square calculated value of 7.890 is less than chi-square table value of 16.92 accepted null hypotheses. There is no variation in the views of male and female community leader on the identified ways of enhancing effective administration of secondary schools in Nigeria.

Hypothesis 5: School location has no significant influence on community leaders perception on the general assessment of secondary school administration in Nigeria.

Df $=9$ chi-square cal $=36.891, \chi^{2}$ table value $=11.07$ Result is significant at 0.05

Since calculated chi-square value of 36.891 is greater than chi-square table value of 11.07 result is significant. The null hypothesis is rejected. There is a difference among the perception of urban, semi-urban and rural community leaders on overall assessment of secondary school administration in Nigeria.

\section{DISCUSSION}

The study revealed that principals and teachers are dedicated to their professional duties; principals controlled the teachers and student effectively. These findings re-consist with those of Akpotu and Oghuvbu (2004). Principals and teachers do not contribute adequately towards community development and majority of them are not educated in the language and culture of the communities were they serve. A god number of the students are familiar with the culture and can speak the language of the community.

The general assessment of secondary school administration by community leaders, who receiv-ed western education during the missionary schools, was unsatisfactory as revealed in this study in table one and three.

The unsatisfactory administration of secondary schools in Nigeria could be responsible for the alleged fall in the standard of secondary education. It could also be the cause of increase in dropout rate, examination malpractice, lack of scientific and technological development in the

Table 7: Chi-square contingency table showing the perception of male and female community leaders on the identified ways of enhancing the effective administration of secondary schools in Nigeria

\begin{tabular}{|c|c|c|c|c|}
\hline \multirow{2}{*}{$\begin{array}{l}S . \\
\text { No. }\end{array}$} & \multirow[t]{2}{*}{ Sex / Type of Leaders } & \multicolumn{2}{|c|}{ Two Likert Scale } & \multirow[t]{2}{*}{ Total } \\
\hline & & Agree & Disagree & \\
\hline 1 & Male Executive Leader & $350 \quad(363.7)$ & $200(196.3)$ & 560 \\
\hline 2 & Female Executive Leader & $88 \quad(90.9)$ & $52(49.1)$ & 140 \\
\hline 3 & Male Retired Teacher & $363(363.7)$ & $197(196.3)$ & 560 \\
\hline 4 & Female Retired Teacher & $80 \quad(90.9)$ & $60 \quad(49.1)$ & 140 \\
\hline 5 & Male Church Leader & $230(227.3)$ & $120(122.7)$ & 350 \\
\hline 6 & Female Church Leader & $241 \quad(227.3)$ & $109(122.7)$ & 350 \\
\hline 7 & Men Leader & $463(454.7)$ & $237 \quad(245.3)$ & 700 \\
\hline 8 & Women Leader & $460 \quad(454.7)$ & $240 \quad(245.3)$ & 700 \\
\hline 9 & Other Male Elder & $223(227.3)$ & $127 \quad(122.7)$ & 350 \\
\hline \multirow[t]{2}{*}{10} & Other Female Elder & $221(227.3)$ & $129(122.7)$ & 350 \\
\hline & Total & 2728 & 1472 & 4200 \\
\hline
\end{tabular}

Source: Computed from fieldwork

Table 8: Chi-square contingency table showing urban male and female, semi-urban male and female community leader perception on the overall assessment of secondary school administration in Nigeria.

\begin{tabular}{llrrrr}
\hline S. & Sex / Type of Leaders & \multicolumn{3}{c}{ Two Likert Scale } & Total \\
\cline { 3 - 5 } No. & & Agree & Disagree & \\
\hline 1 & Male Urban & $315(316.8)$ & 441 & $(439.3)$ & 756 \\
2 & Female Urban & $238(211.2)$ & $266(292.8)$ & 504 \\
3 & Male Semi-urban & $317(316.8)$ & $439(439.2)$ & 756 \\
4 & Female Semi - urban & $233(211.2)$ & $271(292.8)$ & 504 \\
5 & Male Rural & $348(422.4)$ & $660(585.6)$ & 1008 \\
6 & Female Rural & $309(281.6)$ & $363(390.4)$ & 672 \\
\hline
\end{tabular}

Source: Computed from fieldwork 
country because secondary education is the basis for a sound higher education.

School administrators and teachers are not adequately committed towards the eradication of illiteracy, poverty through proper integration of communities with modern scientific and technological developments through teaching and learning. In promoting the administration of secondary school, the study reveals that, all communities should set up education development and monitoring committee and also establish effective Parent Teachers Association in every school under the control of the community leaders. This could lead to positive involvement of communities in the administration of secondary schools resulting in the preservation of the community's culture (Ogbebor, 1992).

Sex and location of communities do not influence the perception of community leaders on teacher's dedication to duty and contribution towards community development, students discipline and involvement in community development and the identified ways of enhancing the administration of secondary schools in Nigeria. These are indications that retired teachers, church leaders and other community leaders are not satisfied with secondary school administration in Nigeria.

\section{CONCLUSIONS AND RECOMMENDATIONS}

Secondary school principals and teachers in Nigeria are dedicated to their professional duty, but do not contribute towards community development. Secondary school students in Nigeria are committed to their studies and are involved in community development on the average.

Community leaders are not satisfied with the administration of secondary schools in Nigeria. The following recommendations are made to reduce the effects of these findings.
All communities in Nigeria should set up education development and monitoring committee.

Establish effective Parent Teachers Association in every school under the control of educated and experienced community leaders.

Community leaders should assist school administrators in the supervision of students (discipline) outside the school.

Community leaders should assist government in the implementation of the Universal Basic Education Programmes, through community laws.

\section{REFERENCES}

Akabue, A. 1997. "The Role of the Communities in Secondary Schools Administration", (Pp. 45-49), in B. S. Okoro (eds.), Dynamics of Educational Administration and Management: The Nigeria Perspective. Awka: Meks Publishers Ltd.

Akpotu, N. E. and E. P. Oghuvbu. 2004. "Performance Appraisal of the Nigeria Secondary School Teachers: The students Perspectives." International Studies in Educational Administration, 32(3): 44 - 54.

Bunnell, S. 1995. Teacher Appraisal in Practice. A Symposium. London: Heinemann Educational Book Ltd.

Federal Republic of Nigeria.1998. National Policy of Education. Lagos, pp. 17 - 24.

Ogbebor, G. G. 1992. "The School and Community Relationship" (Pp. 143-146) in V. F. Peretomode (ed.) Introduced to the Teaching Profession in Nigeria. Lagos: Totan Publishers Ltd.

Oghuvbu, E. P. and P. Iyeke. 2004. "An analysis of Community School Relations; as a peaceable Tool for the Management of Secondary Education." Multidisciplinary Journal of Empirical Research, Ekpoma-Edo State University, Nigeria. 1(1): 71 - 77.

Oghuvbu, E. P. 2000. "Teachers Evaluation of Principals Administrative Effectiveness in Delta State Secondary Schools." West African Journal of Educational Research (WAJER), Calabar - Nigeria, 5(2): 28-40.

Okoro, J. and P. U. Okoro. 2005. "Adopting Joint Funding as a Effective Strategy for Improving Standard in Business Education." Nigerian Journal of Research and Production. 6: 132- 140.

Ozigi, A. O. 1977. A Handbook on School Administration and Management. Lagos: Macmillan Nigeria Publisher Limited. 